\title{
NEWS FROM THE INTERNATIONAL FEDERATION OF ROBOTICS
}

1. Indonesia has been accepted as the newest member of the International Federation of Robotics. The country will be represented by BPP Teknologi, the government agency responsible for the Assessment and Application of Technology.

BPP Teknologi was established by decree in 1978 to assist the President of Indonesia to formulate national policy with regard to the development and application of technology. The agency's responsibilities include assessing technologies which do not exist in Indonesia as well as developing technologies that are presently used there. The agency's evaluation process considers economic, social, cultural and environmental aspects of technologies in addition to the feasibility of their being implemented in Indonesia.

BPP Teknologi's activities in the fields of electronics, robotics, signal and image processing, and manufacturing technologies are carried out by its Control Engineering and Measurement Division, based in Jakarta. The head of this Division, Dr Iman Herwidiana Kartowisastro, will serve as the Indonesian member of the IFR National Co-ordinators committee.

2. The Australian Robot Association now has a presence on the World Wide Web at the URL http://www.cs.uow.edu.au/isase/ara/; in addition to supplying basic information about that Association these pages provide a list of all member associations of the International Federation of Robotics, including contact information.
3. The IFR is endeavouring to establish an archive of videos illustrating robot developments, including current robot applications as well as research results that could lead to future applications. Videos supplied to this archive should be of high image quality and free of copyright restrictions or usage charges, as the IFR intends to make copies of these videos available in standard formats to anyone wishing to see them. A small charge will be levied to cover the costs of opeating this service. Anyone with a suitable video to supply should send this to Mrs Kerstin Teglöf Delgado, International Federation of Robotics, Sveriges Verkstadsindustrier, P.O. Box 5510, 11485 Stockholm, Sweden, giving permission for the video to be added to the IFR archive and to be reproduced by IFR, and indicating briefly the content, format and language of each video submitted.

(Submitted by Michael Kassler, Member Executive Committee, International Federation of Robotics.)

Michael Kassler, Managing Director

Michael Kassler and Associates Pty Ltd

Suite 2, 2 West Crescent Street

McMahons Point NSW 2060, Australia

telephone: +61299593239

fax: +61299594632

e-mail: michaelk@zip.com.au 